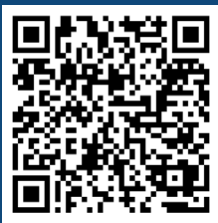

Keywords:

Climate change

Carbon storage

Carbon pools

Forest inventory data

Mediterranean region

Antalya

Konya

Received 26/04/2019

Accepted 14/10/2019

Correspondence: musa_dinc20@artvin.edu.tr
Musa Dinc ${ }^{\text {la }}$, Can Vatandaslar'

\section{ANALYZING CARBON STOCKS IN A MEDITERRANEAN FOREST ENTERPRISE: A CASE STUDY FROM KIZILDAG, TURKEY}

DINC, M.; VATANDASLAR, C. Analyzing carbon stocks in a mediterranean forest enterprise: a case study from kizildag, Turkey. CERNE, v. 25, n. 4, p.402-4I4, 2019.

\section{HIGHLIGHTS}

Forests, grasslands, and agricultural areas are the primary deposits of carbon.

Forests have an enormous storage capacity of carbon compared to other terrestrial ecosystems.

The vast majority of carbon stocked in soil component for each land use/land cover classes.

Special attention should be paid for soil carbon studies.

Negative effects of climate change can be reversed by proper forest management.

\section{ABSTRACT}

Carbon dioxide is one of the most important greenhouse gases responsible for global climate change. Terrestrial ecosystems are widely recognized as useful mechanisms, as they store large quantities of carbon in their bodies. In this context, the present study aims at analyzing carbon stocks in forest (both productive and degraded), grassland, and agricultural ecosystems of Kizildag Planning Unit. To this end, forest inventory data, published statistics, and GIS tools were used for modeling carbon densities of these three ecosystems in a spatially explicit manner. Moreover, carbon contents were estimated for different pools including above- and below-ground biomass, litter layer, deadwood, and soil components. Results showed that a total of nearly 3.5 million tons of carbon stored in the entire study area. When standardized to per unit area, productive and degraded forests stocked the most significant amounts followed by grassland and cropland land use/land cover (LULC) classes. The average density was I 20.8 tons ha-I for productive forests, while it was 32.3 tons ha-I for croplands. The vast majority of these amounts stocked in soil pools for each LULC classes. Therefore, special attention should be paid for soil carbon studies which are very rare in the region. Regarding spatial distribution, Kizildag showed a rather non-homogeneous pattern in terms of carbon densities. Hotspots generally accumulated in the southwestern parts, as well as near the east border of the study area. Carbon densities could be as high as 200-245 tons ha-I in these hotspots. Those areas were dominated by mixed stands of Taurus fir, cedar, and black pine at older ages and they were designated primarily for protective functions in the forest management plan. It is concluded that vast degraded forestlands in the region offer great opportunities to forest managers as an effective mechanism in combatting climate change. Therefore, rehabilitation, afforestation, and forest protection activities should be accelerated as possible. 


\section{INTRODUCTION}

The greenhouse effect has become harmful for the global climate as a consequence of the increased anthropogenic activities in recent centuries. It is considered that the essential part of this effect stemming from carbon dioxide $\left(\mathrm{CO}_{2}\right)$ gases. Thus, international scientific research has been focused on the dynamics of $\mathrm{CO}_{2}$ in the last decades. They indicate that $\mathrm{CO}_{2}$ concentration in the atmosphere has increased from 280 ppm to $412 \mathrm{ppm}$ after the industrial revolution (NOAA, 2013; Sharma et al., 20I I; URL-I). In this context, many global mechanisms such as REDD ${ }^{+}$, Kyoto and LULUCF have been introduced for widely investigate the carbon deposits of terrestrial ecosystems as well as their trading potential to the countries (Aryal et al., 2013).

Among terrestrial ecosystems; forests, grasslands, and agricultural areas are the primary deposits of carbon. These ecosystems play an essential role in the global $\mathrm{CO}_{2}$ cycle since they can sequester carbon and store it in their bodies effectively. Biomass expansion factors are mostly used for determining carbon amounts in these ecosystems. Forests, for instance, have an enormous storage capacity of aboveground biomass compared to other terrestrial ecosystems. They store almost $80 \%$ of global aboveground carbon on their own (Waring and Running, 1998; Asan, 1999). Accordingly, a total of 650 billion tons of carbon is stored within forests all over the world (FAO, 20I0). In a forest ecosystem, carbon is stored in five different pools including (i) aboveground biomass, (ii) belowground biomass, (iii) dead wood, (iv) litter layer and (v) soil. Within these pools, approximately $75 \%$ of the net primary productivity is realized in forest ecosystems worldwide (Melillo et al., 1993).

Grassland ecosystems, on the other hand, are another vital pool, as they contain about $12 \%$ of terrestrial carbon stocks globally (Adams et al., 1990; Ojima et al., 1993). Unlike forests, they store carbon mostly in their belowground components. That is why grasslands are dominated by herbaceous (non-woody) vegetation and they are relatively short-lived due to their perennial lifespan as well as grazing activities. However, their extensive root systems may store almost $80 \%$ of the total carbon in the soil (Glatzle, 20I2). Many studies have been carried out to estimate gross grassland carbon using different methods at various scales (Foody et al., 2003; Kumar et al., 2015). Biomass harvesting is common in these studies (Dinc et al., 2018) although it has significant limitations, as discussed by Jobbagy et al. (2002). Another limitation relates to the high spatial variation of aboveground biomass on grasslands. To overcome such limitations, researchers attribute the aboveground biomass with the data of precipitation, temperature, and soil (Sala et al., 1988; Epstein et al., 1997; Dinc et al., 2018). Along with such datasets, remote sensing products are useful for effectively mapping the complex spatial patterns in large areas (Lauenroth, 1979; Sala et al., 1988; Burke et al., 1997; Jobbagy et al., 2002; Ni, 2004; Fang et al., 2005; Dinc et al., 2018).

Regarding agricultural areas, carbon levels stored both in above- and below-ground biomass strictly depends on the crop characteristics. Therefore, they may markedly differ based on both plant species and its developmental stage (Lichaikul, 2004; Jenkins et al., 2003). More or less, crops are capable of carbon sequestration in the form of accumulated biomass in their stems and soils (IPCC, 2003; IPCC, 2006; FAO, 20I2). Thus, the agriculture sector has also the potential to mitigate global climate change. The critical point here is that decisionmakers should always consider not to have any adverse effect on food production while they are planning to carbon management activities. Otherwise, global food security may be at risk in the future.

The countries that have signed the Kyoto Protocol are obliged to declare their forest resources and their contribution to global carbon cycle. In this context, Turkey has periodically reported both its carbon storage and oxygen production amounts based on landscape-level forest management plans (Seki et al., 2017). However, they are being calculated only for the forested lands and identified by total amounts for forest enterprises. Therefore, carbon storage capacities for neither nonforest lands (e.g., openings without tree) nor other ecosystem types (e.g., grassland, agriculture, etc.) can be determined. Moreover, spatially explicit presentation of these capacities are lacking in the management plans. Yet, it is of crucial importance to know the ratio of storage capacities per unit area belonging to different land use/ land cover (LULC) classes.

The objective of this study is to analyze the carbon storage capacities of forest, grassland, and agricultural ecosystems in the Kizildag Forest Planning Unit (FPU) located at the southern Turkey. To this end, we calculated and mapped the carbon stocks within these ecosystems based on field data and published statistics using spatial analysis methods in a Geographical Information Systems (GIS) software. Furthermore, total carbon stocks were subdivided into its above- and below-ground components such as vegetation, deadwood, and soil. Obtained results are expected to be useful to natural resource managers in their decision-making processes. Another importance of this study lies in the study area, as it is in the most vulnerable sub-region (i.e., the western Mediterranean) to future climate change in Turkey (Özcan et al., 2018; Semerci et al., 2018; Türkeş et al., 2018). 


\section{MATERIAL AND METHODS}

\section{Study area}

Kizildag FPU stretches from 4I25732-415325I N to 353172-4138184 E (UTM Zone36N, WGS84 Datum) and is located between Antalya and Konya provinces in the Mediterranean region of Turkey (Figure I). Its mountainous lands cover 53290 ha with an average slope rate of $31 \%$ (Figure 2). LULC is very heterogeneous with highly diverse tree species (Table I). Moreover, land covers within forest and grassland are mostly degraded. Human-induced degradation is attributed to illegal logging, improper land use and overgrazing (OGM, 2016). The region shows a transition climate type between Mediterranean and continental. Accordingly, summer seasons are hot and dry, while the winters are cold and rainy. The monthly average temperature ranged from $1.8{ }^{\circ} \mathrm{C}$ in January to $23.4^{\circ} \mathrm{C}$ in July with a total annual average precipitation of $564 \mathrm{~mm}$ (SMS, 2018). Based on Erinc's aridity index (Erinc, 1984), the study area is in the arid region due to rain mostly drop in December and January (Figure 3). Summer drought affects a significant part of the planning unit during the vegetation period. It is an essential factor influencing plant growth and its yield when coupled with the sunny aspects (Figure 2). The dominant soil type in the study area is brown forest soil (Ozkan et al., 2007).

\section{Field sampling and modeling}

Forest inventory data were used to determine the biomass amounts in the forest ecosystem. For this purpose, 264 sampling plots were distributed all over the forested lands with a systematical sampling scheme. Circular plot sizes were $400 \mathrm{~m}^{2}, 600 \mathrm{~m}^{2}$ or $800 \mathrm{~m}^{2}$ based on the canopy cover classes. Ground measurements were conducted by professional forest engineers in the summer of 2015. Then, stand parameters including species mixture, diameter at breast height (dbh) and stem quality were recorded into inventory sheets. No measurement was performed in other land use classes except for forests. Accordingly, information on agricultural areas was retrieved from annual statistics published by TUIK (20I6). Grassland data, on the
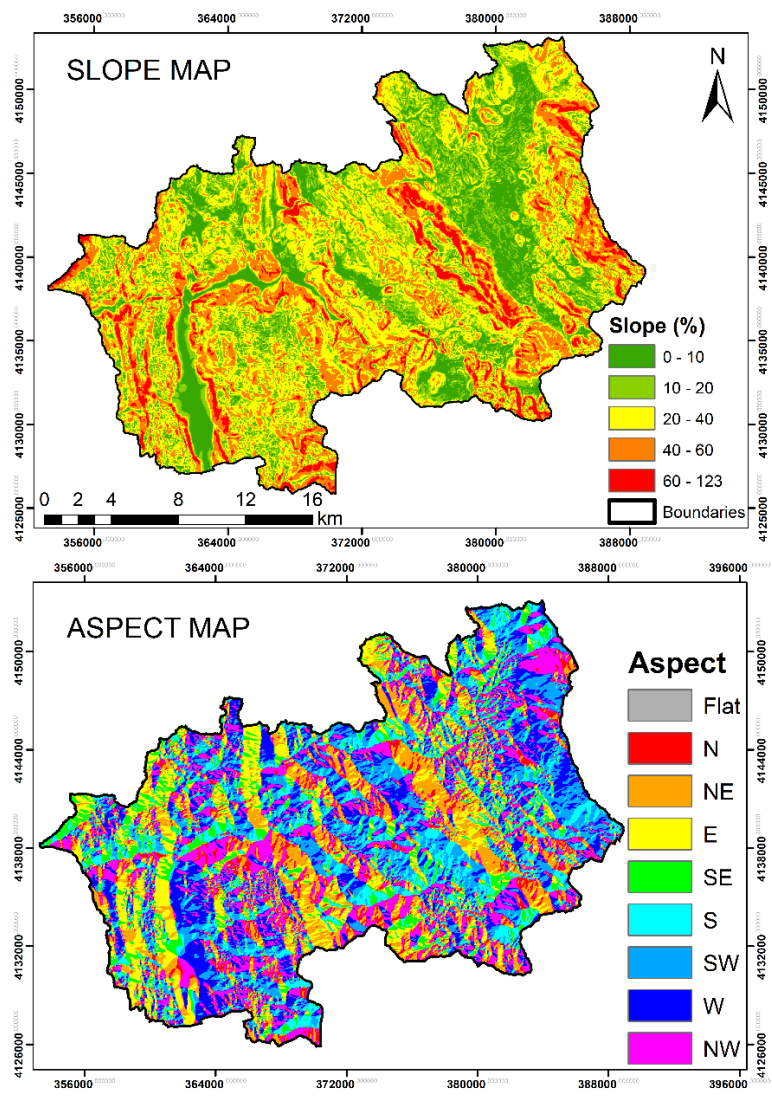

FIGURE 2 Slope and aspect groups map of Kizildag FPU.

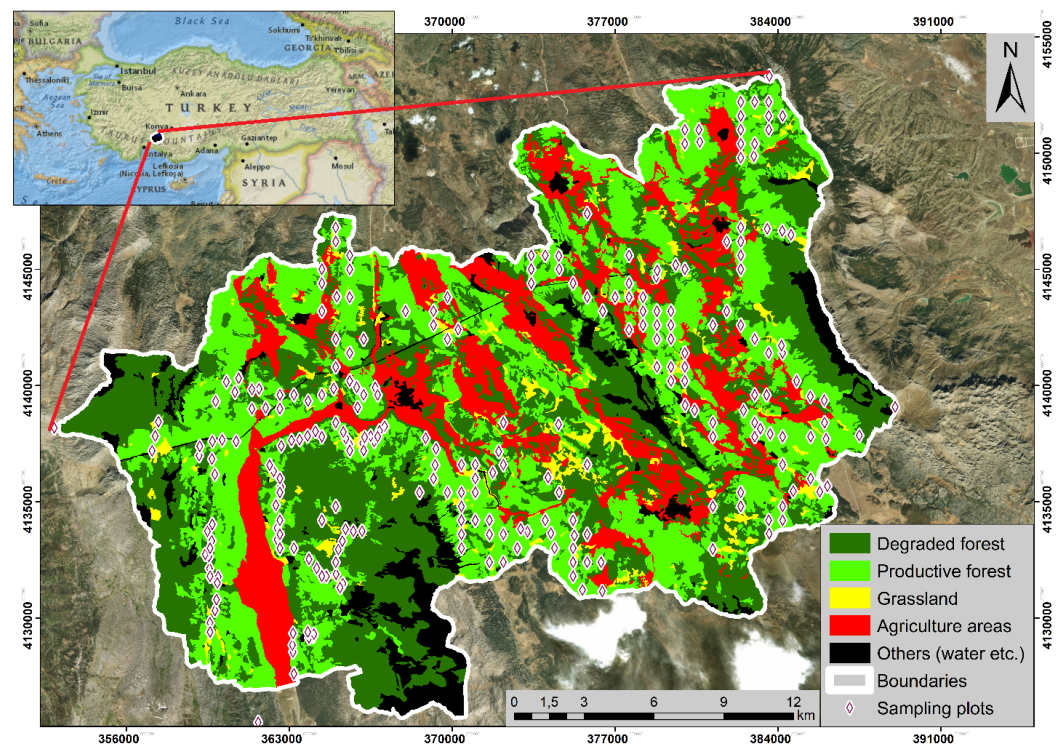

FIGURE I LULC map of Kizildag FPU with sampling plots. 


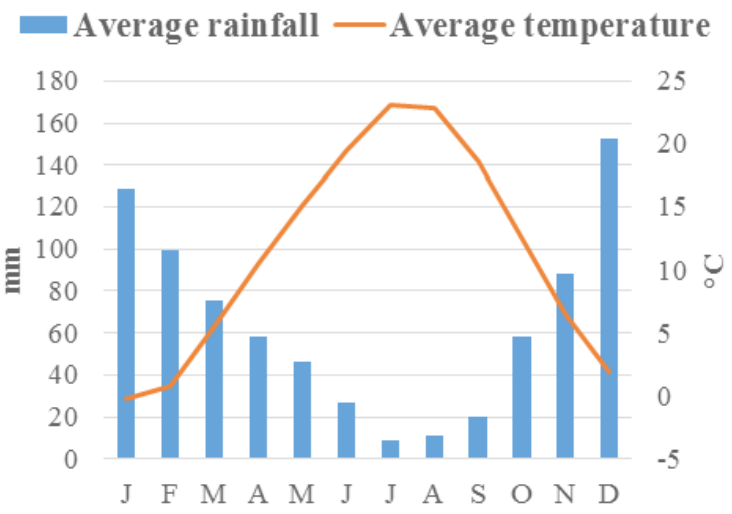

FIGURE 3 Monthly climatic data from the nearest weather station (SMS, 2018).

other hand, was estimated based on Dinç et al. (2018)'s regression model. Finally, a spatial database was set up in ArcGIS software (ESRI, 20I2) and stand type map was generated. Further information on these procedures can be seen in OGM (2017).

\section{Calculation of carbon stocks}

The amount of carbon stored in Kizildag FPU was determined using the inventory-based carbon stock change method (IPCC, 2003; 2006; Serengil, 2018). Accordingly, biomass amounts were first calculated for 5 carbon pools (i.e., aboveground, belowground, litter, deadwood, and soil) in the ecosystem. Then, they were converted to carbon content as explained in the next subsections.

\section{Carbon content in aboveground biomass}

In forested lands, aboveground biomass for each tree in a sample plot was first calculated by multiplying wood density (WD) and biomass expansion factor TABLE I LULC information of Kizildag FPU (OGM, 20I6).

\begin{tabular}{|c|c|c|c|}
\hline LULC & $\begin{array}{l}\text { Area } \\
\text { (ha) }\end{array}$ & $\begin{array}{l}\text { Area } \\
\text { coverage } \\
(\%)\end{array}$ & Dominant species \\
\hline Productive forest & 20140 & 37.8 & $\begin{array}{l}\text { Juniperus sp., Pinus nigra, Abies } \\
\text { cilicica, Juniperus sp., Abies } \\
\text { cilicica, Juniperus sp., Quercus } \\
\text { spp., Pinus nigra, Cedrus libani }\end{array}$ \\
\hline Degraded forest & 19152 & 35.9 & $\begin{array}{c}\text { Juniperus sp., Pinus nigra, Cedrus } \\
\text { libani, Abies cilicica, Quercus spp., } \\
\text { Abies cilicica }\end{array}$ \\
\hline Grassland & 1687 & 3.2 & $\begin{array}{c}\text { Evonymus europad, Hedera helix, } \\
\text { Pteridium agnilineum, Rubus ideus, } \\
\text { Rubus fruticosus, Sumbucus spp., } \\
\text { Urtica dioicar, Fragaria vesca, } \\
\text { Euphorbia amygdaloides, Verbascum } \\
\text { olympicum, Trifolium pretense, } \\
\text { Centaura, Viscum Album, Syclamen } \\
\text { europea, Graminea } \\
\end{array}$ \\
\hline Cropland & 8758 & 16.4 & $\begin{array}{l}\text { Barley, wheat, bean, trefoil, lentil, } \\
\text { corn, chickpea, potato, oat }\end{array}$ \\
\hline $\begin{array}{l}\text { Others (i.e., rocky } \\
\text { areas, water, } \\
\text { settlements etc.) }\end{array}$ & 3553 & 6.7 & - \\
\hline Total & 53290 & 100 & \\
\hline
\end{tabular}

(BEF). WD and BEF coefficients developed by Turkish researchers for native tree species were given in Table 2. Then, carbon amounts were calculated by multiplying aboveground biomass (AGB) with a coefficient of $0.5 \mathrm{I}$ for coniferous and 0.48 for deciduous forests (IPCC, 2006). Finally, these values were aggregated to plot level and converted to per unit area (i.e., I ha).

TABLE 2 Wood densities and biomass expansion factors for primary tree species in Turkey.

\begin{tabular}{|c|c|c|c|}
\hline Tree species & $\begin{array}{l}\text { Wood } \\
\text { density } \\
\left(\mathrm{Mg} \cdot \mathrm{m}^{-3}\right)\end{array}$ & $\begin{array}{c}\text { Biomass } \\
\text { Expansion } \\
\text { Factor }\end{array}$ & Reference \\
\hline Pinus nigra & 0.47 & 1.071 & Cakıl (2008) \\
\hline Abies cilicica & 0.35 & 1.345 & Karabürk $(20 \mathrm{I})$ \\
\hline Cedrus libani & 0.43 & 1.3 & Ülküdür (20I0) \\
\hline J & 0.508 & 1.195 & $\begin{array}{l}\text { As et al. (200I); } \\
\text { Çömez (20I2) }\end{array}$ \\
\hline Quercus spp. & 0.57 & 1.324 & Durkaya (1998) \\
\hline Mixed coniferous forests & 0.431 & 1.222 & Asan (2006) \\
\hline Mixed deciduous forests & 0.55 & 1.239 & \\
\hline Degraded coniferous forests & 0.446 & 1.195 & Tolunay (20I I) \\
\hline Degraded deciduous forests & $0.54 I$ & 1.23 & \\
\hline
\end{tabular}

In grasslands, total biomass was first calculated by Equation I (Dinc et al., 2018) based on the precipitation data obtained from Şarkikaraağaç (MGM, 2019). Then, Lales et al. (200I)'s coefficient (i.e., 0.5) was used for conversion to carbon. Finally, $27 \%$ of this amount was considered as aboveground, while the rest of it stands for belowground carbon content, as suggested by Dinc et al. (2018) for grasslands of Turkey.

Total Biomass $=0.40765+0.00021 \times$ Precipitation

In agricultural lands, both cultivated areas and crop types on them were obtained from the Turkish Statistical Institute's reports (TUIK, 2016). Based on these statistics, aboveground biomass was calculated by the related coefficients in Table 3 for per unit area. Then, carbon amounts were calculated by multiplying AGB with 0.45 , which was a coefficient suggested by Surur et al. (20I3).

TABLE 3 Aboveground biomass and its carbon content for the agricultural sector.

\begin{tabular}{|c|c|c|c|}
\hline Crop type & $\begin{array}{l}\text { Aboveground } \\
\text { biomass } \\
\text { (ton } \cdot \mathrm{ha}^{-1} \text { ) }\end{array}$ & $\begin{array}{l}\text { Aboveground } \\
\text { Carbon } \\
\left(\text { ton } \cdot \mathrm{ha}^{-1}\right)\end{array}$ & Reference \\
\hline Wheat & 4.48 & 2.02 & Başçetinçelik (2005); \\
\hline Barley & 4.92 & 2.21 & $\begin{array}{c}\text { Süzer (2004) } \\
\text { Başçetinçelik (2005); } \\
\text { URL-2 }\end{array}$ \\
\hline Corn & 12.95 & 5.83 & \\
\hline Rye & 4.22 & 1.90 & \\
\hline Oat & 4.48 & 2.02 & $"$ \\
\hline Beans & 4.27 & 1.92 & " " \\
\hline Chickpea & 0.90 & $0.4 \mathrm{I}$ & URL-2 \\
\hline Lentil & 1.35 & 0.61 & $"$ \\
\hline Potato & 2.19 & 0.99 & Başçetinçelik (2005) \\
\hline Vetch & 7.00 & 3.15 & URL-3 \\
\hline Clover & 11.27 & 5.07 & TUIK (2017) \\
\hline Sainfoin & 4.00 & 1.80 & URL-4 \\
\hline
\end{tabular}




\section{Carbon content in belowground biomass}

In forested lands, belowground biomass (BGB) and its carbon equivalent were calculated by the help of IPCC guidelines (i.e., Agriculture, forestry, and other land use guideline) (IPCC, 2003; 2006). Accordingly, root to shoot ratios and carbon factors for temperate forests were utilized depending on forests' structural characteristics such as species and growing stock. Relevant coefficients used in this guideline were given in Table 4.

TABLE 4 Root to shoot ratios and carbon factors for temperate forests (IPCC, 2003; 2006).

\begin{tabular}{cccc}
\hline Community & $\begin{array}{c}\text { Aboveground biomass } \\
\left(\text { ton } \cdot \mathrm{ha}^{-1}\right)\end{array}$ & $\begin{array}{c}\text { Root to } \\
\text { shoot ratio }\end{array}$ & Carbon factor \\
\hline \multirow{3}{*}{ Coniferous } & $<50$ & 0.40 & \multirow{2}{*}{0.51} \\
\cline { 2 - 3 } & $50-150$ & 0.29 & \\
\cline { 2 - 3 } Deciduous & $>150$ & 0.20 & \multirow{2}{*}{0.48} \\
\cline { 2 - 3 } & $<75$ & 0.46 \\
\cline { 2 - 3 } & $75-150$ & 0.23 & 0.24 \\
\hline
\end{tabular}

As for grasslands, total biomass was first calculated by Equation I given in the previous section. Then, 73 $\%$ of this amount was considered as BGB as suggested by Dinc et al. (2018). Finally, the carbon content was multiplied with 0.5 which was a conversion coefficient reported by Lales et al. (200I).

In agricultural lands, BGB was calculated by multiplying AGB with 0.12, which was a conversion coefficient (Surur et al., 20I3). Subsequently, the carbon content was calculated by multiplying BGB with 0.45 , which was a conversion coefficient for agricultural lands (Surur et al., 20I3).

\section{Carbon content in litter}

In forested lands, the weights of the litter layer were first determined by each stand depending on the dominant tree species for per unit area. Organic matter in these weights was then calculated. Finally, carbon content in the organic matter was found by the help of the average values given in Table 5. These values were developed by extensive studies conducted in Turkey between I95I and 2008. No calculations were made for non-forested lands.

TABLE 5 Organic carbon densities in litter layer for Turkey

\begin{tabular}{|c|c|c|c|c|}
\hline Group of Species & $\begin{array}{l}\text { Litter } \\
\text { (ton'ha-1) }\end{array}$ & $\begin{array}{l}\text { Organic Matter } \\
\left(\text { ton } \cdot \mathrm{ha}^{-1}\right)\end{array}$ & $\begin{array}{l}\text { Organic Carbon } \\
\left(\text { ton } \cdot \mathrm{ha}^{-1}\right)\end{array}$ & References \\
\hline Pinus nigra & 26.5 & 17.2 & 8.6 & Sevim (195I); Kantarcı (2000); Sevgi (2003); Celik (2006) \\
\hline Abies cilicica & 37 & 28.5 & 14.2 & Kantarcı (1979b); Kantarcı (2000) \\
\hline Cedrus libani & 19.8 & 14.2 & 7.1 & Karaöz (1993); Karaöz and Sevgi (1997); Zengin (1998) \\
\hline Juniperus sp. & 10.3 & 7.3 & 3.7 & Çelik (2006) \\
\hline Quercus spp. & 8.6 & 6.2 & 3.1 & $\begin{array}{l}\text { Özyuvacı (1976); Kantarcı (1983); Makineci (1993); Sevg } \\
\text { (I993); Özer (1993); Öztürk (1993); Çelik (2006) }\end{array}$ \\
\hline Juniperus sp.- Pinus nigra & 4 & 2.6 & 1.3 & Celik (2006) \\
\hline Pinus nigra-Quercus spp. & 13 & 9 & 4.5 & Özer (1993); Kantarcı (2000); Çelik (2006) \\
\hline Juniperus sp.- Quercus spp. & 8.1 & 3.4 & $\mathrm{I}, 7$ & Çelik (2006) \\
\hline Degraded coniferous forests & & & 1.86 & Tolunay and Çömez (2008) \\
\hline Degraded deciduous forests & & & 0.93 & $l^{\prime \prime}$ \\
\hline
\end{tabular}

\section{Carbon content in deadwood}

Forest inventory data were used for calculating deadwood biomass of each tree at the plot level. Then, the carbon content was calculated by multiplying the deadwood biomass with 0.47 as reported by the Turkish Forest Management Guideline (FRA, 2010; OGM, 2017). No calculations were made for non-forested lands.

\section{Carbon content in soil}

In forested lands, soil carbon was determined using the average values given in Table 6. These values were developed by tree species for both degraded and productive forests based on extensive field studies conducted in Turkey between 1974 and 2008. In grasslands, on the other hand, the values reported by Dinc (2017) were used. For agricultural lands, finally, the values suggested by Parlak et al. (2008) were directly employed.

TABLE 6 Soil carbon densities of Turkey's forests.

\begin{tabular}{|c|c|c|}
\hline Group of Species & $\begin{array}{l}\text { Soil Carbon } \\
\left(\text { ton } \cdot \mathrm{ha}^{-1}\right)\end{array}$ & References \\
\hline Pinus nigra & 71.6 & $\begin{array}{l}\text { Kantarcı (1979a); Eruz (1984); } \\
\text { Sevgi (2003); Özkan (2003); } \\
\text { Celik (2006) }\end{array}$ \\
\hline Abies cilicica & 82.6 & Özkan (2003) \\
\hline Cedrus libani & 85.7 & $\begin{array}{c}\text { Özkan (2003); Başaran et al. } \\
\text { (2008) }\end{array}$ \\
\hline Juniperus sp. & 64.4 & $\begin{array}{l}\text { Özkan (2003); Çelik (2006); } \\
\text { Başaran et al. (2008) }\end{array}$ \\
\hline Quercus spp. & 82.3 & $\begin{array}{c}\text { Kantarcı (1974); Özhan (1977); } \\
\text { Kantarcı (1979a); Kantarcı } \\
\text { (1983); Karaöz (1988); Sevgi } \\
\text { (1993); Makineci (1999); Kara } \\
\text { (2002); Özkan (2003); Çelik } \\
\text { (2006); Başaran et al. (2008) }\end{array}$ \\
\hline Cedrus libani-Juniperus sp. & 71.5 & $\begin{array}{l}\text { Özkan (2003); Bassaran et al. } \\
\text { (2008) }\end{array}$ \\
\hline Abies cilicica-Juniperus sp. & 92.8 & Özkan (2003) \\
\hline Cedrus libani-Pinus nigra & 50.8 & \\
\hline Abies cilicica-Pinus nigra & 62.9 & $"$ \\
\hline Pinus nigra-Juniperus sp. & 40.5 & Özkan (2003); Celik (2006) \\
\hline Pinus nigra-Quercus spp. & 52.6 & - \\
\hline Quercus spp.-Juniperus sp. & 44.7 & " \\
\hline Degraded forest & 79.6 & Tolunay and Çömez (2008) \\
\hline Grassland & 37.1 & Dinç $(2017)$ \\
\hline Cropland & 29.7 & Shah et al. (2015) \\
\hline
\end{tabular}




\section{Total carbon stocks}

Total carbon stocks were calculated by summing up all available carbon pools for each ecosystem type. Equation 2, Equation 3, and Equation4 were used for forest, grassland and agriculture ecosystems, respectively, where TC is the total carbon stock, AGC is the aboveground carbon stock, BGC is the belowground carbon stock, DWC is the carbon stock in deadwood, LC is the carbon stock in litter layer, SC is the carbon stock in the soil.

$$
\begin{aligned}
& \mathrm{TC}=\mathrm{AGC}+\mathrm{BGC}+\mathrm{DWC}+\mathrm{LC}+\mathrm{SC} \\
& \mathrm{TC}=\mathrm{AGC}+\mathrm{BGC}+\mathrm{SC} \\
& \mathrm{TC}=\mathrm{AGC}+\mathrm{BGC}+\mathrm{SC}
\end{aligned}
$$

\section{RESULTS AND DISCUSSION}

\section{Carbon densities by LULC classes}

The carbon density in productive forest class ranged between 73 and 246.5 tons $\cdot \mathrm{ha}^{-1}$ with a mean of 120.8 tons ha $^{-1}$ (Table 7). It had the highest density among all LULC classes. Kauppi et al. (1992), Gifford et al. (1992) and Lee et al. (2015) also found mean carbon densities of 122 tons ha $^{-1}$ in Europe, 128 tons ha ${ }^{-1}$ in China, and I 30 tons $\cdot \mathrm{ha}^{-1}$ in Korea's forests, respectively. They related the higher carbon densities to the areas dominated by mixed forest ecosystems. In another study conducted near the Kizildag FPU, higher carbon storages were estimated in mixed forest stands, as well (Mirici et al., 2015). Similarly, the higher carbon stocks were observed in Fir-Cedar mixed stands in this study, as discussed in the next section. Thus, it can be said that our results - in general - are in good agreement with the relevant literature.

The biomass carbon density (i.e., the summed of above- and below-ground carbon values) was 37.9 tons $\mathrm{ha}^{-1}$ for productive forests in the present study. Tolunay (20I I), in another study, found a mean value of 41.7 tons $\cdot$ ha $^{-1}$ for Turkey's forests while UN-ECE/FAO (2006) reported it as 43.9 tons $\cdot$ ha $^{-1}$ for European forests.
Although there are some marginal values which are lower than 37.9 tons ha-1 (Dixon et al., 1994; Evrendilek, 2014), our finding is slightly smaller than the essential literature. The main reason for that may be the harsh environmental conditions within the study area. As seen in Figure 2, almost half of Kizildag FPU has a slope rate of more than $40 \%$. This causes the soil to remain shallow. As a result, the soil cannot store enough water which is essential for plant growth. Indeed, large quantities of tree mortalities are widespread in the Mediterranean region. In a recent study conducted in this region (Semerci et al., 20I8), almost $30 \%$ of the growing stock was found to be dieback, especially in Taurus Fir stands. They attributed this phenomenon to severe drought stress in the last decades. Taurus Fir was dominant tree species in Kizildag FPU, as well.

Specific emphasis should also be given to other carbon pools including soil, litter, and deadwood in forest ecosystems. The soil carbon, in particular, is generally overlooked in total carbon calculations due to lack of relevant data. However, the amount of carbon stored in forest soils is much higher than those of biomass. It was determined by the dynamic interaction between organic matter entry and decomposition of this matter (Tolunay and Çömez, 2007). Fallen leaves from trees are the first entry for abundant organic matter in the soil (Pausas, 1997). However, decomposition of fine roots also contributes to this amount (Berg et al., 2003). Aside from the soil, the litter layer is another carbon pool in a high forest. A mean of 8.7 tons $\cdot$ ha $^{-1}$ carbon was stored within the litter layer in Kizildag FPU. In another study by Misır et al. (20I3), it ranged from 2 tons ha- ${ }^{-1}$ to 7 tons $\mathrm{ha}^{-1}$ in Giresun, Turkey. The differences can be attributed to both stand types and tree species. The researchers studied in a pure Beech forest which was intensively managed by relatively short rotations. The stand types in Kizildag, on the other hand, is dominated by mixed- or Fir-species managed primarily for protective functions.

Unlike forests, the lowest carbon density was observed in croplands. It was between 30.2 and 45.7 tons

\begin{tabular}{|c|c|c|c|c|c|c|c|}
\hline LULC class & & $\begin{array}{c}\text { Aboveground C } \\
\left(\text { ton } \cdot h^{-1}\right)\end{array}$ & $\begin{array}{c}\text { Belowground C } \\
\left(\text { ton } \cdot \mathrm{ha}^{-1}\right)\end{array}$ & $\begin{array}{c}\text { Litter C } \\
\left(\text { ton } \cdot h^{-1}\right)\end{array}$ & $\begin{array}{c}\text { Deadwood C } \\
\left(\text { ton } \cdot h^{-1}\right)\end{array}$ & $\begin{array}{c}\text { Soil C } \\
\left(\text { ton } \cdot h^{-1}\right)\end{array}$ & $\begin{array}{c}\text { Total C } \\
\left(\text { ton } \cdot \mathrm{ha}^{-1}\right)\end{array}$ \\
\hline \multirow{3}{*}{ Productive forest } & Min. & 3.2 & 0.9 & 1.4 & 0 & 41 & 73 \\
\hline & Avg. & 29.4 & 8.5 & 8.7 & 1.2 & 73 & 120.8 \\
\hline & Max. & 114 & 33 & 14 & 41 & 92.8 & 246.5 \\
\hline \multirow{3}{*}{ Degraded forest } & Min. & 0.8 & 0.2 & 1.7 & 0 & 40 & 46.4 \\
\hline & Avg. & 1.4 & 0.4 & 4.3 & 0 & 45.2 & 51.3 \\
\hline & Max. & 1.9 & 0.6 & 7.2 & 0 & 64 & 71.1 \\
\hline Grassland & Avg. & 0.8 & 2.2 & 0 & 0 & 37.1 & 40.1 \\
\hline \multirow{3}{*}{ Cropland } & Min. & 0.4 & 0.1 & 0 & 0 & & 30.2 \\
\hline & Avg. & 2 & 0.6 & 0 & 0 & 29.7 & 32.3 \\
\hline & Max. & 5.8 & 7.5 & 0 & 0 & & 45.7 \\
\hline
\end{tabular}
$\mathrm{ha}^{-1}$ with a mean of 32.3 tons ha $^{-1}$ (Table 7). More than

TABLE 7 Carbon densities within the different pools by LULC classes in per ha basis. 
$90 \%$ of this amount (i.e., 29.7 tons $\cdot$ ha $^{-1}$ ) stored only in the soil. Similarly, Shah et al. (20I5) reported that 32.7I tons $\cdot$ ha $^{-1}$ carbon stored in the soil of Pakistan's croplands. Grassland LULC class, on the other hand, showed a carbon density of 40.1 tons $\cdot$ ha $^{-1}$ in the present study. As seen in Table 7, there was no range within grasslands due to the calculation method we used. However, it can be said that they have nominal storage capacity in their different carbon pools. There are many grassland studies conducted in Turkey reporting similar results to ours (Dinc, 2018; Kendir, 1999; Yavuz et al., 2013; Bilgin, 20I0). Laswai (20I I), on the other hand, found a carbon density value of 65.8 ton.ha- ${ }^{-1}$ for Tanzania's grasslands. These kind of higher values should be considered ordinary since water is an essential part of plant growth in grasslands and Kizildag suffers from summer drought as can be seen in Figure 3. Furthermore, the rate of AGB is expected to decrease in the summer season, while it increases for BGB. Therefore, both temporal and seasonal changes should be taken into account in such studies, as already reported by Kahmen et al. (2005).

\section{Density maps for different carbon pools}

The finding of the present study revealed that both aboveground and belowground carbon densities were the highest in productive forests. The spatial distribution of these two essential carbon pools can be seen in Figure $4 \mathrm{a}$ and Figure 4b. The similarity between two maps was evident in the figures. However, carbon densities of them were totally different as seen in their legends. The green hotspots showing high storage capacities located at both southern and northern parts of the Kizildag FPU. According to forest stand type map, these areas generally consisted of mixed (Cedar-Fir) forest stands that were at higher age-classes from 80 to 140 years old. Thus, they had a lot of large-girth trees whose $\mathrm{dbh}$ classes were $\mathrm{d}(36-52 \mathrm{~cm})$ and e $(>52 \mathrm{~cm})$ in the Turkish forest management system (OGM, 2017).

The litter carbon densities were mapped for degraded and productive forest LULC classes (Figure 4c). Accordingly, litter carbon hotspots were generally aggregated in the northwestern parts of Kizildag. Pure fir or fir-dominated mixed stands were common in these areas. Another distinctive feature of these stands was that they were almost fully-covered at all. The lowcapacity regions, which were shown in red color on the map, located at both the center and the eastern parts of the study area. These areas generally consisted of degraded (i.e., canopy cover < $10 \%$ ) forest stands.

The deadwood carbon density was mapped only for productive forests. Regarding deadwood carbon,
Kizildag showed a relatively homogenous pattern as seen in Figure 4d. Red colors were dominant in the available areas indicating very low-capacity of carbon storage in deadwood. Few hotspots existed (e.g., in orange color) in the regions with mature forests. These forest stands overlapped with the hotspots of above- and below-ground carbon density maps showed in Figure $4 \mathrm{a}$ and Figure 4b. It may be attributed to the extensive management practices on these sites. Indeed, these sites are mainly allocated to soil protection function in the forest management plan (OGM, 2016) due to the high slope rates higher than $60 \%$. Therefore, no or minimal intervention is performed to these forest sites. Higher deadwood amounts can be explained in this way. The deadwood carbon densities in Figure $4 \mathrm{~d}$ ranged between 0 and $4 \mathrm{I}$ tons ha ${ }^{-1}$ with an average of $I .2$ tons ha ${ }^{-1}$. It was about $4 \%$ of the average aboveground carbon density as seen in Table 7. Karahalil et al. (2017) conducted a comprehensive study on deadwood near Kizildag. They obtained similar findings to ours. According to this study, the mean deadwood volume constituted only $2.4 \%$ of the total standing volume in Koprulu Canyon National Park, Antalya. The slight difference may be attributed to different tree species in two study areas. Unlike us, they studied in a Calabrian pine-dominated forest.

As for soil carbon density, a non-homogenous spatial pattern was observed in the study area. Different patches of both high- and low-capacity sites existed together. However, the darkest green hotspots dominated the northwestern parts of the Kizildag FPU (Figure 4e). These sites spatially correlated with litter carbon density map (Figure 4c). There were also many hotspots in the eastern parts. In general, they consisted of mixed stands of Juniper and Fir with various developmental stages. This finding is in agreement with Özkan (2003)'s study. He has investigated different site factors in forest ecosystem near the Beysehir Lake which is very close to our study area. He found that soil carbon amount in Fir-Cedar mixed forest was the highest among other forest types. Interestingly, many degraded stands showed a high-capacity of carbon storage in the soil in our case.

\section{Total carbon density at the landscape level}

In order to map the total carbon stock, all maps in Figure 4 were overlapped and aggregated into one GIS layer. It was seen that red and yellow colors were dominant in the final map (Figure 5). This was indicating very low- and moderate-capacities of carbon storages were typical for the entire FPU. In general, the 


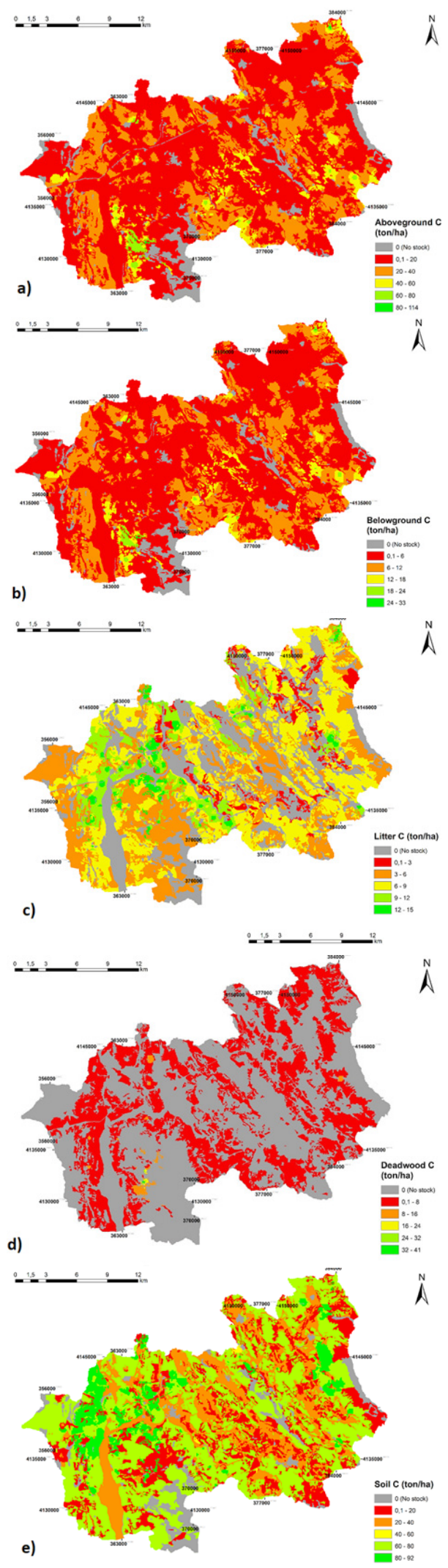

FIGURE 4 Carbon density maps of Kizildag FPU. Carbon pools of aboveground (a), belowground (b), litter (c), deadwood (d), and soil (e). areas presenting moderate-capacities consisted of the productive forest with different characteristics in terms of tree species and developmental stages. Grasslands and croplands, on the other hand, located at the very low-capacity sites colored in red. Degraded forests dominated the orange sections showing low-capacities. There were some exceptions, as expected. Some of the green hotspots, for example, consisted of old-growth forest sites which were designated for nature protection in the forest management plan (OGM, 2016). The mixed forest stands dominated other hotspots. These hotspots had large-girth Fir, Cedar, and Black Pine trees that were common in the region. Mirici et al. (2015), Kauppi et al. (1992), Gifford et al. (1992) and Lee et al. (2015)'s studies were also consistent with the present study. They found the highest carbon values in mixed forest ecosystems in their study areas. Finally, the grey areas on the map had no carbon stocks. They were irrelevant LULC classes; settlement, mine sites, rocky areas etc. Among these, the power line located in the east-west direction can be seen in the upper part of the study area in Figure 5.

The total carbon stock was calculated as 3404828 tons for the entire study area (Table 8). Forest was the best LULC class in Kizildag FPU in terms of maximum carbon storage capacity. Nearly $90 \%$ of the total carbon stored only in forest ecosystems both in their degraded and productive types. Grassland, on the other hand, was the worst LULC class as it could save only $2 \%$ of the total carbon amount. The remaining carbon (ca. $8 \%$ ) was retained by croplands covering $16 \%$ of the whole study area (Table 8). As expected, vast differences were observed amongst the different LULC classes. Nevertheless, these differences were affected by the area coverage of LULC classes across the planning unit, as well.

There were also significant differences among carbon contents in the different components ( $\mathrm{C}$ pools) of LULC classes at the landscape level. In productive forests, for example, approximately $60 \%$ of the total carbon

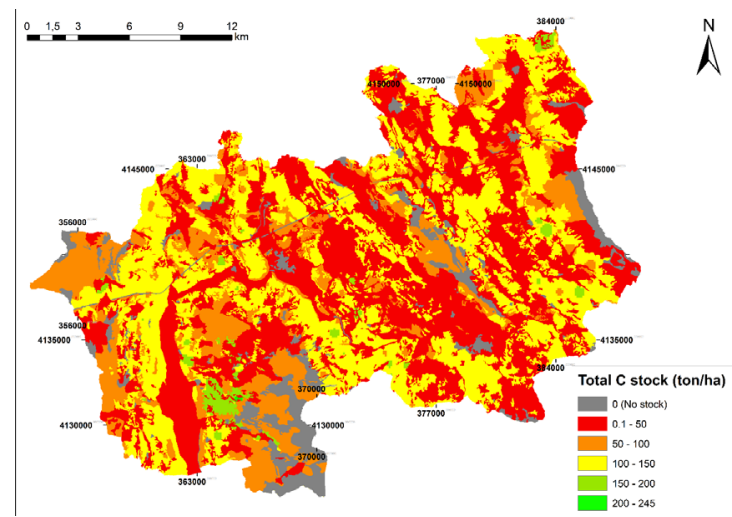

FIGURE 5 Total carbon stock map of the Kizildag FPU. 
TABLE 8 Total carbon stocks and their distribution across LULC classes.

\begin{tabular}{|c|c|c|c|c|c|c|c|}
\hline $\begin{array}{l}\text { LULC } \\
\text { class }\end{array}$ & $\begin{array}{l}\text { Aboveground C } \\
\text { (ton) }\end{array}$ & $\begin{array}{l}\text { Belowground C } \\
\text { (ton) }\end{array}$ & $\begin{array}{l}\text { Litter C } \\
\text { (ton) }\end{array}$ & $\begin{array}{c}\text { Deadwood C } \\
\text { (ton) }\end{array}$ & $\begin{array}{l}\text { Soil C } \\
\text { (ton) }\end{array}$ & $\begin{array}{c}\text { Total C } \\
\text { (ton) }\end{array}$ & $\%$ by LULC coverage \\
\hline Productive forest & 478364 & 138372 & 140987 & 19811 & 1195923 & 1973457 & 57.96 \\
\hline Degraded forest & 24511 & 6878 & 81784 & 0 & 968001 & 1081174 & 31.75 \\
\hline Grassland & 1349 & 3711 & 0 & 0 & 62511 & $6757 \mid$ & 1.98 \\
\hline Cropland & 19957 & 2549 & 0 & 0 & 260120 & 282626 & 8.31 \\
\hline All LULCs & $524|8|$ & 151510 & 22277 I & |98II & 2486555 & 3404828 & 100 \\
\hline$\%$ by $\mathrm{C}$ pools & 15.40 & 4.45 & 6.54 & 0.58 & 73.03 & 100 & \\
\hline
\end{tabular}

stored in the soil while it was only $1 \%$ in deadwood. This amount could increase as high as $90 \%$ in favor of soil in other LULC classes (Table 8). Taking all LULC classes together, the distributions into carbon components were app. $73.0 \%$ for soil, $15.4 \%$ for aboveground, $6.5 \%$ for litter, $4.5 \%$ for belowground, and $0.6 \%$ for deadwood. As seen in Table 8 , almost $3 / 4$ of the total amount stored in the soil in Kizildag FPU.

\section{CONCLUSION}

In the present study, the amounts and spatial distribution of carbon stocks for forest, grassland and agriculture ecosystems were analyzed within the boundaries of the Kizildag FPU. The total stock was found to be as almost 3.5 million tons at the landscape level. Carbon hotspots were generally located at the southwestern parts of the study area which were adjacent to Kimyos Plain. These parts were the old-growth and mixed forest sites designated for protective functions. When standardized and allocated into ecosystem types, average stocks were 120.8 tons $\mathrm{ha}^{-1}, 5 \mathrm{I} .3$ tons ha40.I tons ha ${ }^{-1}$, and 32.3 tons ha- ${ }^{-1}$ for productive forest, degraded forest, grassland, and cropland, respectively. Regarding carbon pools, the soil was seen as an essential component for stocking. It was obviously the best pool followed by aboveground biomass in terms of carbon storage in its body.

It is concluded that forest ecosystems with their productive and degraded forms are crucial for carbon management. They have a considerable potential for stocking significant amounts of carbon in their different components. By utilizing the density maps presented in this study, forest managers could improve the capacity of degraded ecosystems covered more than one-third of the Kizildag's lands by proper forestry activities such as rehabilitation, afforestation, and protection. Thus, alleviating the harmful effects of climate change might be a viable option at least at the landscape level. In time, we believe that more effort will be spent and successful results will be achieved in combatting climate change both at national and global levels.

\section{REFERENCES}

ADAMS, J.M.; FAURE, H.; FAURE-DENARD, L.; MCGLADE, J.M.; WOODWARD, F.I. Increases in terrestrial carbon storage from the last glacial maximum to the present. Nature. v.348, 7| I-7I4, 1990.

ARYAL, S; BHATTARAI, D.R.; DEVKOTA, R.P. Comparison of carbon stocks between mixed and pine-dominated forest stands within the Gwalinidaha Community Forest in Lalitpur District, Nepal. Small-scale Forestry. v. 12, n.4, 659-666, 2013.

AS, N.; KOÇ, H.; DOĞU, D.; ATIK, C.; AKSU, B.; ERDINLER, S. Growing Concern in Turkey Anatomical Industrial Wood Physics, Mechanical and Chemical Properties. Istanbul University, Faculty of Forestry Journal, 200I.

ASAN, U. Climate change, carbon sinks and the forests of Turkey. In: Proceedings of the International Conference on Tropical Forests and Climate Change: Status, Issues and Challenges (TFCC '98), the Philippines, p. 157-170, 1999.

ASAN, U. Final Report for the LULUCF Forestry Group Concerning the Estimation of Net Annual Amount of Carbon Uptake or Release in the Forests of Turkey. 2006.

BAŞARAN, M.A.; BAŞARAN, S.; KAÇAR, S.; BAŞ, N.; TOLUNAY, D.; MAKINECI, E.; KAVGACI, A.T.; DENIZ, I.G. Determining the actual state of research forest Elmali cedar by GIS based digital maps. T.C. Çevre ve Orman Bakanlığı tarafından desteklenen (ARA 6) 19.6302/200 I2007 no.lu proje, (in Turkish), 2008.

BAŞÇETINÇELIK, A.; KARACA, C.; ÖZTÜRK, H.H.; KACIRA, M.; EKINCI, K. Agricultural biomass potential in Turkey. Proceedings of the 9th International Congress on Mechanization and Energy in Agriculture and 27th International Conference of CIGR Section IV: The Efficient Use of Electricity and Renewable Energy Sources in Agriculture: Sep.27-29, 2005. Izmir-TURKEY, 195-199, 2005.

BERG, B.; MCCLAUGHERTY, C. Decomposition, humus formation, carbon sequestration. Plant Litter. Germany. 3-540-44329-0, 2003.

BILGIN, F. Investigating changes on vegetation and some soil properties with altitude in high pasturelands near Aydin Village in Ardanuç, Artvin. Master thesis, Artvin Coruh University, 9I pages, (in Turkish), 2010. 
BURKE, I.C.; LAUENROTH, W.K.; PARTON, W.J. Regional and temporal variation in net primary production and nitrogen mineralization in grasslands. Ecology. v.78, 1330-1340, 1997.

ÇAKIL, E. Zonguldak Orman Bölge Müdürlüğü karaçam biyokütle tablolarının düzenlenmesi. Master thesis. Zonguldak Karaelmas University, 167 pages, (in Turkish), 2008.

ÇELIK, N. Site characteristics and classification on Sündiken Mountains. Master thesis. Istanbul University, (in Turkish), 2006.

ÇÖMEZ, A. Determination of Carbon Sequestration in Scots Pine (Pinus Sylvestris L.) Stands On Sündiken Mountain. PhD thesis. Istanbul University, (in Turkish), 2012.

DINC, M. Determination and Modelling of Above Ground and Below Ground Carbon Contents in Forest, Grassland and Agriculture Areas with Association by Using Satallite Images in Some Sub-Basins of Artvin, Erzurum and Bayburt. PhD Thesis. Artvin Coruh University, 232 pages (in Turkish), 2017.

DINC, M.; VATANDASLAR, C.; DUMAN, A.; TUFEKCIOGLU, M.; KUCUK, M.; ACIKGOZ HARSIT, C.; TUFEKCIOGLU, A. Estimating Biomass and Carbon Storage of Grasslands Using Very High- Resolution Satellite Images In The Coruh River Basin (Northeastern Turkey). Fresenius Environmental Bulletin. v27 - No. 8/20I8 pages 5509-5519, 2018.

DIXON, R.K.; BROWN, S.; HOUGHTON, R.A.; SOLOMON, A.M.; TREXLER, M.C.; WISNIEWSK, J. Carbon pools and fluxes of global forest ecosystems. Science. v263: 185190, 1994.

DURKAYA, B. Construction of biomass tables of qquercus in Zonguldak Forest Region administration. Zonguldak Karaelmas University, Master thesis. 110 pages, (in Turkish), 1998.

EPSTEIN, H.E.; LAUENROTH, W.K.; BURKE, I.C. Effects of temperature and soil texture on ANPP in the U.S. Great Plains. Ecology. v.78, 2628-263I, 1997.

ERUZ, E. The relationships between some edaphic and physiographic features with the height development of pure larch stands in Balıkesir Forestry Directorate. İstanbul University, Publication No: 3244, Matbaa Teknisyenleri Basımevi. İstanbul, (in Turkish), 1984

ERINÇ, S. Climatology and Its Methods, Third ed. Güray Pres Inc, Istanbul (in Turkish), 1984.

ESRI. ArcGIS 10.2. Environmental Systems Research Institute Inc., California, 2012.

EVRENDILEK, F. An inventory-based carbon budget for forest and woodland ecosystems of Turkey. Journal of Environmental Monitoring. v6, 26-30 2004.

FANG,J.Y.; PIAO, S.L.;ZHOU, L.M.; HE,J.S.;WEI, F.Y.; MYNENI, R.B.; TUCKER, C.J.; TAN, K. Precipitation patterns alter growth of temperate vegetation. Geophysical Research Letters. 32, 2005.
FAO. Global Forest Resources Assessment, 2010: Country Report. Turkey. FAO, Rome, Italy. (http://www.fao.org/ docrep/0I3/al649E/al649e.pdf), 2010.

FAO. Food and agriculture organization of the United Nations. FAO. Rome, Italy (http://www.fao.org/3/a-i3028e.pdf), 2012.

FOODY, G.M.; BOYD, D.S.; CUTLER, M.E.J. Predictive Relations of Tropical Forest Biomass from Landsat TM Data and Their Transferability between Regions. Remote



FRA. Global Forest Resource Assessment Country Report. Forest Department Food and Agriculture Organization of the United Nations. Rome, 2010.

GIFFORD, R. M.; CHENEY, N. P.; NOBLE, J.; RUSSELL, J. S.; WELLINGTON, B.; ZAMMIT, C. Australian land use, primary production of vegetation and carbon pools in relation to atmospheric $\mathrm{CO}_{2}$ concentration. In Gifford, R. M., Barson, M., eds. Australia's renewable resources: sustainability and global change, pp. I5I-I87. Bureau of Rural Resources Proceedings. No. 14. Canberra, AGPS, 1992.

GLATZLE, A. La ganadería chaqueña su impacto al medio ambiente. Proceedings of the II Congreso Nacional de Ciencias Agrarias. Universidad Nacional de Asunción, San Lorenzo, Paraguay, 2I-23 March 20I2. p. 30-32, 2012.

IPCC. Good Practice Guidance for Land Use, Land-Use Change and Forestry. Institute for Global Environmental Strategies (IGES). Hayama, Japan, ISBN 4-88788-003-0, 2003.

IPCC. Guidelines for National Greenhouse Gas Inventories. Volume 4: Agriculture, Forestry and Other Land Uses. 678 p, 2006.

JOBBAGY, E.G.; SALA, O.E.; PARUELO, J.M. Patterns and controls of primary production in the Patagonian steppe: a remote sensing approach. Ecology. v83, 307-319, 2002.

JENKINS, J.; CHOJNACKY, D.; HEATH, L.; BIRDSEY, R. National-scale biomass estimators for United States tree species. Forest Science. v 49, n. I, p. I2-35, 2003.

KAHMEN, A.; PERNER, J.; BUCHMANN, N. Diversity dependent productivity in semi natural grasslands following climate perturbations. Functional Ecology. v.19, p.59460I, 2005.

KANTARCI, M.D. Changes in some features of forest soil by transforming the forest into pastures and fields around a forest village in Thrace. Istanbul University, Journal of the Faculty of Forestry. Series A, v.14, n.I, p.191-217, (in Turkish), 1974.

KANTARCI, M.D. Analytical investigation of the horizons of the soils and silicates of soils under mild climatic conditions. Istanbul University, Journal of the Faculty of Forestry. Series A, v.29, n. I, p. I4-53, (in Turkish), 1979a. 
KANTARCI, M.D. The investigation of some of the dead cover and soil properties of the Aladağ (Bolu) in Uludağ Fir forests according to the climatic zones. Istanbul University Press, Publication No: 2634, (in Turkish), 1979b.

KANTARCI, M.D. Effects of Soil Preparation and Soil Processing on Soil Properties and Development of Coastal Pine Saplings. Istanbul University, Journal of the Faculty of Forestry, Serie A, v.33, n.22:104-140, (in Turkish), 1983.

KANTARCI, M.D. Toprak ilmi ders kitabı. Istanbul University Press, (in Turkish), 2000.

KARA, Ö. Seasonal changes of the soil microfungi in the pure stands of beech, oak and pine at the mountainous site of Northern Thrace. Istanbul University, PhD thesis, XII+ I 40 pages, (in Turkish), 2002.

KARABÜRK, T. Arrangement of biomass tables of Bartın province fir stands. Bartın University, Master thesis. 173 pages, (in Turkish), 20ll.

KARAHALIL, U.; BAŞKENT, E.Z.; SIVRIKAYA, F;; KILIÇ, B. Analyzing deadwood volume of Calabrian pine (Pinus brutia Ten.) in relation to stand and site parameters: a case study in Köprülü Canyon National Park. Environ Monit Assess, v189, II2, 2017.

KARAÖZ, M.Ö. Comparison of the important edaphic properties of some coniferous and broadleaf forest ecosystems in terms of biomass characteristics in Belgrad Forest. İstanbul University, PhD thesis. (VII+203 pages), (in Turkish), 1988.

KARAÖZ, M.Ö.; SEVGI, O. The relationships between development of tree species used in afforestation and growing environment factors in Balıkesir Değirmenboğazı. Istanbul University. Scientific Research Project (882/060896), (IV+ I 72 pages), (in Turkish), 1997.

KARAÖZ, M.Ö. Investigations on the amount of litter and the nutrient reserves of some local and foreign needle tree species. Istanbul University, Journal of the Faculty of Forestry, Series A, v.43, n. I, p.93-I I 5, (in Turkish), 1993.

KAUPPI, P.E.; MIELIKAINEN, K.; KUSELA, K. Biomass and carbon budget of European forests, I97I to 1990. Science. v.256, p.70-74, 1992.

KENDIR, $H$. Vegetation composition, forage yield and range condition of a natural rangeland in Ayaş (Ankara). Journal of Agricultural Sciences, v. 5, n. I, p. I04-I I0, (in Turkish), 1999.

KUMAR, L.; SINHA, P.; TAYLOR, S.; ALQURASHI, A.F. Review of the use of Remote Sensing for Biomass Estimation to Support Renewable Energy Generation. Journal of Applied Remote Sensing. v.9, p.097696, 2015.

LALES, J.S.; LASCO, R.D.; GERONIMO, I.Q. Carbon storage capacity of agricultural and grasslands ecosystems in a geothermal block. The Philippine Agricultural Scientist. v.84, n.I, p.8-18, 2001 .
LASWAI, F.F. Carbon storage potential of grassland ecosystems in the eastern Arc Mountains: A case study of Udzungwa Mountains, Tanzania. Master thesis. Sokoine University of Agricultre. Morogoro, Tanzania, $201 \mathrm{I}$.

LAUENROTH, W.K. Grassland primary production: North American grasslands in perspective. In: French, N.R. (Ed.). Perspectives in Grassland Ecology. New York, pp. 3-24, 1979.

LEE, S.H.; JANG, R.H.; CHO, K.T.; YOU, Y.H. Budget and distribution of organic carbon in Quercus serrata Thunb. Ex Murray forest in Mt. Worak. Journal of Ecology Environment. v. 38, n.4, p.425-436, 2015.

LICHAIKUL, N. Change of soil carbon stock and sequestration after conversion of forest to reforestation and agricultural lands. Master thesis. King Mongkut's University of Technology Thonburi, 2004.

MAKINECI, E. Investigation on the ecological aspects of the reproduction methods applied in the oak forests in Demirköy. Istanbul University, Master thesis. 77 pages, (in Turkish), 1993.

MAKINECI, E. The effects of the conversion of coppice treatments on nitrogen alteration of forest floor and soil in research forest of İstanbul University forestry faculty. Istanbul University, PhD thesis. ( $X X I V+2 I 3$ pages), (in Turkish), 1999.

MELILLO, J.M.; MCGUIRE, A.D.; KICKLIGHTER, D.W.; MOORE, B.; VOROSMARTY, C.J.; SCHLOSS, A.L. Global climate change and terrestrial net primary production. Nature. V.240, n.363, p.234, 1993.

MGM. Turkish State Meteorological Service. https:// www.mgm.gov.tr/veridegerlendirme/ ilve ilceler-istatistik. aspxkundefined\&m Isparta. (Visited on: February, 10, 2019), 2019.

MISIR, M.; SEÇIL, E.; SINEM, Ş. Adaptation to carbon storage function in forest management plans. Proceedings of the international symposium for the 50th anniversary of the forestry sector planning in Turkey. Proceedings Book. 2628 Kasım 20I3/ANTALYA, (in Turkish), 2013.

MIRICl, E. M.; BERBEROĞLU, S.; ÇILEK, A. The Use of geomatic technologies with the purpose of estimating terrestrial carbon storage capacity at a level of forest. Electronic Journal of Map Technologies. Vol: 7, No: 3, 2015 (2I33), 2015.

NI, J. Estimating net primary productivity of grasslands from field biomass measurements in temperate northern China. Plant Ecology., v. I74, n.2, 21 7-234, 2004.

NOAA. Atmospheric $\mathbf{C O}_{2}$ Mauna Loa Observatory (Scripps/ NOAA/), 2013.

OGM. Kizildag Forest Management Plan for the period 20162035. General Directorate of Forestry. Ankara (in Turkish), 2016. 
OGM. Ecosystem-based Multifunctional Forest Planning Guideline of Turkey (Code: 299). General Directorate of Forestry. Ankara (in Turkish), 2017.

OJIMA, D.S.; DIRKS, B.O.; GLENN, E.P.; OWENSBY, C.E.; SCURLOCK, J.O. Assessment of $C$ budget for grasslands and drylands of the world. Water, Air and Soil Pollution. 109, 79:95-109, 1993.

ÖZER, B. Investigation of dead cover properties of pure pine and pine + oak mixed stands in afforestation areas in Demirköy, Istanbul University, Master thesis $(\mathrm{XI}+120$ pages), (in Turkish), 1993.

ÖZCAN, O.; MUSAOĞLU, N.; TÜRKEŞ, M. Assessing vulnerability of a forest ecosystem to climate change and variability in the western Mediterranean sub-region of Turkey. Journal of Forest Research. v29 (3):709-725, 2018.

ÖZHAN, S. Change of hydrologically important properties of dead covering according to some local factors in Belgrad forest Ortadere basin. Istanbul University Press. Publication No. 2330, İstanbul, (in Turkish), 1977.

ÖZKAN, K. Properties and classification of sites on Beyşehir Watershed. Istanbul University, $\mathrm{PhD}$ thesis. $(\mathrm{XVI}+189$ pages), (in Turkish), 2003.

ÖZKAN, K.; MERT, A.; GÜLSOY, S. Relationships between soil colour, soil structure and some soil properties in Beyşehir watershed. Süleyman Demirel University. Journal of the Faculty of Forestry. Seri: A, Sayı: 2, YIl: 2007, ISSN: I 3027085, Sayfa: 9-22, 2007.

ÖZTÜRK, H. Investigation on the effects of litter characteristics in Demirköy degraded forest. Istanbul University, Master thesis. (in Turkish), 1993.

ÖZYUVACI, N. Hydrologic characteristics of the Arnavutkoy creek watershed as influenced by some plant-soil-water relations. Istanbul University Press. Publication No: 2082, 1976.

PARLAK, M.; FIDAN, A.; KIZILCIK, I.; KOPARAN, H. Determination of the fertility status of Eceabat-Çanakkale agricultural soils. Journal of Agricultural Sciences. v. 14 , n.4, 394-400, 2008.

PAUSAS, J.G. Litter fall and litter decomposition in Pinus sylvestris forests of the Eastern Pyrenees. Journal of Vegetation Science. v8, 643-650, 1997.

SALA, O.E.; PARTON, W.J.; JOYCE, L.A.; LAUENROTH, W.K. Primary production of the central grassland region of the

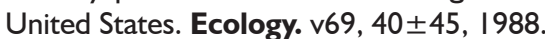

SEKI, M; SAKICI, O.M.; BÜYÜKTERZI, M.; SAĞLAM, F. Temporal changes in carbon stock of Taşköprü Forest Enterprise forests. Proceeding in International Taşköprü Pompeiopolis Science Culture Research Symposium. 10-12 April 2017 Kastamonu, Turkey, 2017.
SEMERCI, A.; VATANDASLAR, C.; OZDEMIR, A. Intensive Tree Mortality of Taurus Fir (Abies cilicica) in Mediterranean Forests of Turkey. Proceeding in International Symposium Ecology 2018. 19-23 June 2018 Kastamonu, Turkey, 2018.

SERENGIL, Y. İklim değişimi ve karbon yönetimi. UNDP Turkey, (in Turkish), 2018.

SEVGI, O. Properties of soil which is under the forest and clear cutter areas in the forest at granite land of Demirköy. Istanbul University, Master thesis. (VIII+83 pages), (in Turkish), 1993.

SEVGI, O. Altitudinal nutrition growth relations of black pine (Pinus nigra Arnold) at Bayramiç Forest Enterprise (Kaz mountains). Istanbul University, $\mathbf{P h D}$ thesis. (XV+22I pages), (in Turkish), 2003.

SEVIM, M. Ecological and pedological researches in Alaçam (Dursunbey) forest. Istanbul University, Journal of the Faculty of Forestry. Serie A, V I(2): I I5- I42, I95I.

SHAH, S.; IQBAL, J.; AHMAD, A.; KHAN, A. Soil organic carbon stock estimation in range lands Kumrat Dir Kohistan KPK Pakistan. Journal of Ecology and the Natural Environment. Vol 7 (I I), pp. 277-288, 2015.

SHARMA, C.M.; GAIROLA, S.; BADUNI, N.P.; GHILDIYAL, S.K.; SARVESH, S. Variation in Carbon Stocks on Different Slope Aspects in Seven Major Types of Temperate Region of Garhwal Himalaya, India. Journal of Biosciences. v36, 70I-708, 20II.

SMS. Climate records of the Seydisehir weather station. State Meteorological Service, Ankara, 2016.

SURUR, K.; ALIREZA, K.; MEHDI, N.M.; REZA, K.; REZA, G. Evaluation of carbon sequestration potential in corn fields with different management systems. Soil and Tillage Research. vI33 25-3I, 2013.

SÜZER, S. The importance of wheat harvest. Hasad Bitkisel Üretim Dergisi. v289: 17-25, (in Turkish), 2004.

TOLUNAY, D.; ÇÖMEZ, A. Carbon storage and situation in forest land in Turkey. Forests Symposium on global climate change and water problems. Proceedings Book. I3- I4 Aralık 2007, İstanbul, (in Turkish), 2007.

TOLUNAY, D.; ÇÖMEZ, A. Amounts of Organic Carbon Stored in Forest Floor and Soil in Turkey. National Symposium on Air Pollution and Control. Proceedings Books. 22-25 Ekim 2008, Hatay. 750-765, (in Turkish), 2008.

TOLUNAY, D. Total carbon stocks and carbon ccumulation in living tree biomass in forest ecosystems of Turkey. Turkish Journal of Agriculture and Forestry. v35, 265-279, 201 I.

TUIK. Published statistics from Turkish Statistical Institute. http://rapory.tuik.gov.tr. (Visited on. January, I0, 2019), 2016. 
TUIK. Published statistics from Turkish Statistical Institute. http://rapory.tuik.gov.tr/I5:28:58II349546941922347/8I236 818535.html. (Visited on. January, 04, 2019), 2017.

TÜRKEŞ, M.; MUSAOĞLU, N.; ÖZCAN, O. Assessing the vulnerability of a forest ecosystem to climate change and variability in the western Mediterranean sub-region of Turkey: future evaluation. Journal of Forest Research. v.29, n.5, II77-II86, 2018.

UN-ECE/FAO. Global forest resources assessment 2005, global assessment of growing stock, biomass and carbon stock. United Nations Economic Commission for Europe (Geneva), Food and Agriculture Organization of the United Nations, Forestry Department. Working paper. I06/E, Rome, pp. 54, 2006.

URL- I. https://www.CO. earth/ (Visited on: March, 22, 2019).

URL-2. http://www.eziraatci.com/turkiyedearpaveriminekadar.html. (Visited on: March, 18, 2019).
URL-3.http://www.kappadokiatohum.com/UrunlerDetay. aspx?id=87 (Visited on: April, 0I, 2019).

URL-4.htt p://www.tarimkutuphanesi.com/ korunga_00578.html (Visited on: March, 04, 2019).

ÜLKÜDÜR, M. Construction biomass tables of cedar in Antalya regional forest directorate. Bartın University, Master thesis. XVI+ I47 pages, (in Turkish), 2010.

WARING, R.; RUNNING, S.W. Forest Ecosystems: Analysis at Multiple Scales. San Diego: Academic Press. 1998.

YAVUZ, R.; KARAGÜL, R. The effect of some improvement methods on the yield and quality of the range. Journal of Central Research Institute for Field Crops. v.22, n.2, p.96-104, 2013.

ZENGIN, M. Some hydro-physical properties of forest floor and soils of differents stands. Journal of the Poplar and Fast Growing Forest Trees Research Institude. No. 12, Kocaeli, (in Turkish), 1998. 